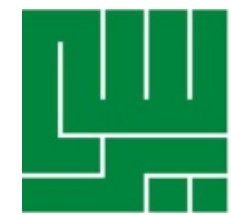

\title{
Pengembangan Alat Ukur Mindful Parenting untuk Orang Tua dari Remaja di Indonesia
}

\section{The Development of Mindful Parenting's Scale for Parents with Adolescent in Indonesia}

\author{
Grin Rayi Prihandini ${ }^{1}$, Lia Mawarsari Boediman ${ }^{2}$, Lely Nur Azizah ${ }^{3}$, \\ Veronica Kristiyani ${ }^{4}$, Gistilisanda $\mathrm{FH}^{5}$ \\ Fakultas Psikologi Universitas Indonesia \\ Email: 'Igrin.rayi71@ui.ac.id, ${ }^{2}$ lboediman72@gmail.com, ${ }^{3}$ lely.nur71@ui.ac.id, \\ ${ }^{4}$ veronica.kristiyani@ui.ac.id, ${ }^{5}$ gistilisanda.fauzin@ui.ac.id
}

\section{KATA KUNCI Mindful Parenting, Pengasuhan, Mindfulness, Orang tua, Remaja.}

KEYWORDS Mindful Parenting, Parenting, Mindfulness, Parents, Adolescents.

ABSTRAK Pengasuhan orang tua memiliki dampak terhadap perkembangan anak. Pada anak remaja, pengasuhan orang tua memiliki fungsi penting dalam melindungi remaja dari perilaku berisiko dan kenakalan remaja. Pengasuhan yang berlandaskan kesadaran penuh pada anak dirasa penting untuk diterapkan oleh orang tua untuk menurunkan kemungkinan masalah pada remaja. Tujuan dari penelitian ini adalah merancang alat ukur mindful parenting yang reliabel, valid, dan sesuai dengan teori yang digunakan. Penelitian ini melibatkan sejumlah 402 responden untuk mengisi kuesioner sebanyak 60 aitem. Pada akhirnya alat ukur ini menghasilkan 30 aitem terpilih yang reliabel dan valid dalam mengukur konstruk mindful parenting $(\mathrm{CR}=0,93 ; \mathrm{r}=0,362$; $\mathrm{p}<0,01$; one tailed). Hal ini menunjukkan bahwa instrumen ini dapat digunakan untuk mengukur mindful parenting di Indonesia. Dengan adanya pengembangan alat ukur mindful parenting untuk orang tua yang memiliki anak remaja di Indonesia, diharapkan dapat menjadi bahan pertimbangan bagi guru dan psikolog dalam melakukan preverensi dan intervensi terhadap perilaku kenakalan remaja. Lebih lanjut, pada penelitian selanjutnya, dapat dilakukan uji coba kembali terhadap aitem terpilih pada partisipan yang lebih banyak dan beragam agar makin menggambarkan populasi di Indonesia.

ABSTRACT Parenting has an impact on child development. In adolescents, parenting has an important function in protecting adolescents from risky behavior and juvenile delinquency. Parenting based on mindfulness is considered important to be implemented by parents to reduce the possibility of behavior problems in adolescents. The purpose of this study is to design a mindful parenting instrument that is reliable, valid, and in accordance with the theory that used in constructing this instrument. This study involved a total of 402 respondents to fill out 60 item questionnaires. This 
study resulted a mindful parenting instrument with 30 selected items that is reliable and valid to measure mindful parenting construct $(C R=0.93$; $r=0.362 ; p<0.01 ;$ one-tailed. This concluded that this instrument can be used to measure mindful parenting in Indonesia. As the development of mindful parenting instrument for parents who have adolescent in Indonesia, it is expected to be a material consideration for teachers and psychologists in conducting the prevention and intervention of delinquency in adolescents. Furthermore, the further research is expected to re-test the selected items in more number and diverse participants so it can be more representative of population in Indonesia.

\section{PENDAHULUAN}

Orang tua memiliki peran yang penting dalam pengasuhan anak. Pengasuhan adalah salah satu tugas yang menantang karena menentukan kualitas generasi selanjutnya (Kabat-Zinn \& Kabat-Zinn, 2014). Akan tetapi, tidak semua orang tua mampu menjalankan peran tersebut dengan baik. Hal ini tercermin dari beberapa fenomena yang menunjukkan kelalaian orangtua dalam pengasuhan anak yang berakibat fatal. Pengasuhan yang kurang sesuai dapat berdampak pada perkembangan perilaku anak seperti masalah kenakalan remaja (Zaslow, dkk, 2006; Chapple, Tyler \& Bersani, 2005).

Bandura (dalam Feist \& Feist, 2008) juga menyebutkan bahwa lingkungan sosial termasuk didalamnya adalah orang tua dan keluarga, merupakan salah satu prediktor yang mampu meramalkan perilaku kenakalan remaja. Melalui pola asuh yang efektif, orangtua dapat mencegah resiko munculnya perilaku yang negatif dan mendorong perilaku yang positif pada remaja (Duncan, Coatsworth, \& Greenberg, 2009). Perilaku pengasuhan, seperti disiplin yang konsisten, interaksi yang hangat dan mendukung, serta menghabiskan waktu yang berkualitas dengan anak, dapat menurunkan tingkat perilaku yang bermasalah pada remaja (Cabrera, Fitzgerald, Bradley, \& Roggman, 2014).

Coatsworth, Duncan, Greenberg dan Nix (2009) mengatakan bahwa hal yang penting dalam aspek pengasuhan adalah mindfulness. Istilah mindfulness pada pola pengasuhan disebut mindful parenting yang berarti adanya perhatian penuh dan kesadaran dalam melakukan pola pengasuhan antara orang tua dan anak. Mindful parenting ini penting karena dapat mengurangi perilaku bermasalah pada remaja (Bluth \& Wahler, 2011). Penelitian yang dilakukan Glatz dan Buchanan (2015) mendukung hasil penelitian-penelitian lainnya yang menyatakan bahwa orangtua melalui praktik pengasuhannya berperan penting dalam memprediksi terjadinya perilaku menyimpang pada remaja.

Salah satu tahap perkembangan yang sangat memerlukan mindfulness dalam parenting adalah selama masa transisi menuju remaja. Hal ini disebabkan remaja rentan terhadap perilaku-perilaku beresiko seperti tawuran, penyalahgunaan narkoba, merokok, seks bebas dan jenis-jenis kenakalan remaja lainnya. Penelitian menunjukkan adanya hubungan antara mindfulness dan externalizing problems pada remaja, yaitu Ibu yang memiliki tingkat mindfulness yang tinggi memprediksi masalah eksternal yang rendah pada remaja (Bluth \& Wahler, 2011). Penelitian lainnya menunjukkan bahwa disposisi mindfulness pada orangtua berhubungan dengan menurunnya tingkat masalah internalizing dan externalizing melalui tingkat mindful parenting yang tinggi dan penerapan negative parenting yang rendah (Parent, McKee, Rough, \& Forehand, 2015). Selain itu, mindful parenting yang dilakukan oleh orang tua membuat anak merasa memiliki bentuk kelekatan yang baik (secure attachment) dengan orang tuanya, yang kemudian 
memengaruhi well-being remaja yang lebih baik (Medeiros, Gouveia, Canavarro, \& Moreira, 2016). Orang tua yang menerapkan mindful parenting juga memengaruhi perkembangan psikososial remaja melalui meningkatnya selfcompassion yaitu sikap penuh kasih sayang dan empati terhadap kesulitan orang lain, dan mindfulness yang lebih baik pada remaja (Moreira, Gouveia, \& Canavarro, 2018). Keduanya dilihat sebagai faktor internal diri yang penting dalam memengaruhi keberhasilan penyesuaian diri remaja (Moreira, Gouveia, \& Canavarro, 2018).

Melihat eratnya kaitan antara perilaku pengasuhan orangtua secara spesifik yaitu mindful parenting terhadap perkembangan remaja, penting untuk memberikan perhatian terhadap isu ini. Dalam rangka mengurangi angka kenakalan remaja serta meningkatkan perkembangan remaja yang positif, perlu dilakukan suatu bentuk usaha, baik dalam ranah prevensi maupun intervensi terhadap orang tua remaja. Bentuk prevensi maupun intervensi ini dapat dilakukan oleh siapa saja, baik oleh orang tua itu sendiri, guru, maupun tenaga konselor dan psikolog. Sebelum kita dapat melakukan suatu bentuk prevensi maupun intervensi tersebut kita perlu mengetahui bagaimana gambaran mindful parenting orangtua tersebut. Alat ukur ini penting untuk melihat bagaimana gambaran kondisi mindful parenting orang tua yang memiliki anak remaja di Indonesia, sehingga dapat dijadikan bahan pertimbangan untuk usaha preventif maupun intervensi terhadap perkembangan remaja.

Sebelumnya terdapat dua alat ukur mindful parenting. Pertama dibuat oleh Duncan pada tahun 2007 untuk ayah dan ibu dengan anak usia 10-14 tahun (Duncan, 2017). Kedua, McCaffrey pada tahun 2015 membuat instrumen mindful parenting ayah dan ibu yang memiliki anak berusia 2-16 tahun (McCaffrey, Reitman, \& Black, 2017). Studi menunjukkan bahwa kedua alat ukur tersebut masih terdapat beberapa kekurangan yaitu belum mampu membedakan bagaimana gambaran pola asuh pada ayah dan ibu dalam menerapkan mindful parenting (McCaffrey, Reitman, \& Black, 2017). Selain itu, kedua alat ukur yang sudah ada belum mencakup rentang usia remaja di Indonesia. Melihat fenomena dan karakteristik remaja yang unik serta rentan terhadap kenakalan remaja, dirasa perlu dibuat alat ukur baru untuk melihat mindful parenting pada orang tua yang memiliki anak usia remaja secara khusus (12-20 tahun).

Penelitian ini bertujuan untuk menghasilkan alat ukur mindful parenting yang memiliki konsistensi internal yang tinggi, valid, dan memiliki norma yang baik. Diharapkan penyusunan alat ukur ini dapat membantu untuk melihat tingkat mindful parenting pada orang tua yang memiliki anak remaja. Alat ukur ini penting untuk dibuat karena hasil asesmen dari instrumen ini dapat dijadikan bahan untuk membuat usaha preventif maupun intervensi terhadap orang tua remaja.

Selain itu, dengan mengetahui tingkat mindful parenting pada orang tua diharapkan orangtua akan sadar mengenai pentingnya pengasuhan yang dilakukan yang kemudian akan memberi dampak pada perkembangan remaja yang lebih baik. Orang tua yang sadar akan dampak dari pengasuhannya, akan berusaha mencegah resiko munculnya perilaku remaja yang negatif dan mendorong perilaku yang positif, yaitu melalui pola pengasuhan yang mindful. Dengan demikian, diharapkan pengembangan alat ukur mindful parenting ini dapat mengarahkan pada usaha untuk meningkatkan mindful parenting orang tua yang memiliki remaja di Indonesia.

\section{Mindful Parenting}

Konsep mengenai mindful parenting ini dikembangkan oleh Jon Kabat Zinn dan Myla Kabat Zinn pada tahun 1997 (KabatZinn, 2013). Konsep ini merupakan perluasan dari konsep mindfulness. Istilah mindfulness didefinisikan sebagai suatu kesadaran yang berasal dari perhatian pada kondisi saat ini tanpa melakukan penilaian 
apapun terhadap pikiran, perasaan, dan sensasi yang timbul (Kabat-Zinn, 2013). Berdasarkan definisi tersebut, Kabat-Zinn dan Kabat-Zinn (2014) mendefinisikan mindful parenting sebagai suatu tindakan pengasuhan orang tua yang berlangsung secara terus menerus dengan tujuan untuk meningkatkan kesadaran dan kemampuan orang tua untuk hadir dan bertindak secara bijaksana terhadap anak. Dengan demikian, dapat dikatakan bahwa konsep mindfulness merujuk pada kondisi seseorang sebagai individu, terlepas dari segala konteks, sedangkan mindful parenting lebih spesifik merujuk pada kondisi orang tua dalam konteks pengasuhan.

Mindful parenting berarti bahwa orang tua selalu memberikan perhatian, keterbukaan dan kebijaksanaan pada saat orang tua bersama anak. Mindful parenting disini juga termasuk di dalamnya melibatkan pikiran orang tua untuk memahami hal yang benar-benar penting dalam menjalankan aktivitas sehari-hari bersama dengan anak. Mindful parenting juga terkait tentang kemungkinan untuk memperhatikan dan mendengarkan kebutuhan anak dengan lebih jelas dan memercayai diri dan hati sendiri (KabatZinn \& Kabat-Zinn, 2014).

Disisi lain, Duncan, Coatsworth, dan Greenberg (2009) mendeskripsikan bahwa mindful parenting mengacu pada pengurangan dari sikap reaktif dari orangtua dan diiringi dengan adanya peningkatan dari kesabaran, fleksibilitas, tanggung jawab, dan konsistensi dalam pengasuhan yang sesuai dengan tujuan dan nilai yang dimiliki oleh orang tua mindful parenting dianggap sebagai cara untuk mengurangi praktik pengasuhan yang negatif melalui penggunaan strategi pengasuhan yang lebih efektif dengan meningkatkan rasa percaya dan berbagi secara emosional antara orangtua dan anak (Duncan, Coatsworth, \& Greenberg, 2009).

Dalam menyusun alat ukur ini, maka definisi mindful parenting yang digunakan adalah definisi dari Kabat-Zinn dan KabatZinn (2014) yaitu suatu tindakan pengasuhan orang tua yang berlangsung secara terus menerus dengan tujuan untuk meningkatkan kesadaran dan kemampuan orang tua untuk hadir dan bertindak secara bijaksana terhadap anak. Lebih lanjut, Kabat-Zinn mengatakan bahwa orang tua yang menerapkan mindful parenting memiliki pengendalian (sovereignty), empati (empathy), dan penerimaan (acceptance). Definisi Kabat-Zinn dan Kabat-Zinn dipilih karena definisi tersebut merupakan definisi mutakhir yang telah dikembangkan tokoh yang pertama kali mengembangkan teori mengenai mindful parenting yang kemudian dijadikan acuan oleh tokoh lain.

\section{Elemen Mindful Parenting}

Menurut Kabat-Zinn (dalam Kabat Zinn \& Kabat Zinn, 2014) terdapat tiga elemen dari mindful parenting, yakni pengendalian (sovereignty), empati (empathy), dan penerimaan (acceptance). Pengendalian (Sovereignty) yaitu suatu kondisi ketika orang tua mampu untuk mengendalikan diri atau sikap dalam merespon berbagai perilaku anak disesuaikan dengan tujuan pengasuhan orang tua terhadap anak. Pengendalian yang dilakukan oleh orang tua terhadap anak bukan berarti melakukan pemaksaan kehendak orang tua terhadap anak namun pengendalian tersebut didasarkan pada pemahaman bahwa anak memiliki kehendak bebas, karakteristik perilaku, sifat yang perlu dihargai dan diarahkan sesuai tujuan pengasuhan yang akan dicapai.

Empati (Empathy) yaitu suatu keadaan ketika orang tua dapat memahami hal yang dialami dan dirasakan oleh anak sekaligus memiliki kepekaan terhadap kebutuhan anak serta mampu memahami dirinya. Empati juga berarti orang tua memiliki pandangan yang luas untuk dapat memahami kondisi dan perilaku yang ditampilkan anak. Orang tua juga dapat melihat berbagai hal dari sudut pandang anak melalui komunikasi yang dilakukan, sehingga hubungan emosional antara anak dan orang tua dapat terjalin. 
Penerimaan (Acceptance) yaitu suatu keadaan ketika orang tua mampu menerima perasaan, kondisi yang terjadi pada dirinya sekaligus dapat menerima perasaan anak serta segala sesuatu yang ada dan terjadi pada anak. Penerimaan yang dilakukan orang tua terhadap anak bukan berarti menerima dan menyetujui semua perilaku anak. Sebaliknya, orang tua diharapkan tidak menampilkan perilaku reaktif untuk memberikan penilaian baik dan buruk, benar dan salah pada dirinya dan ketika anak menampilkan perilaku tertentu. Orang tua juga diharapkan dapat menerima dan melihat niat positif dibalik setiap perilaku yang ditampilkan oleh anak sehingga orang tua dapat membantu anak untuk dapat mengekspresikan perasaan mereka. Selain itu, dengan adanya penerimaan terhadap diri, diharapkan orang tua dapat membantu dirinya sendiri untuk menemukan solusi terhadap permasalahan yang dihadapi.

Konsep mindful parenting ini walaupun terdiri dari ketiga elemen tetapi pengukurannya bersifat unidimensional. Artinya, ketiga elemen tersebut membentuk skor tunggal dari mindful parenting.

Berdasarkan konsep mindful parenting yang dikembangkan Kabat Zinn tersebut, Duncan pada tahun 2007 mengembangkan alat ukur yang dinamakan Interpersonal Mindfulness Parenting (IEM-P) yang terdiri dari 10 aitem. Alat ukur tersebut digunakan untuk ibu dengan anak berusia 10-14 tahun (McCaffrey, Reitman, \& Black, 2017). Kemudian pada tahun 2009, Duncan memperbaiki alat ukur IEM-P menjadi IMP dengan menambahkan jumlah aitem menjadi 31 aitem (de Bruin dkk, 2014).

McCaffrey juga mengembangkan alat ukur berdasarkan keterbatasan yang ditemukan pada alat ukur IEM-P dan IMP, seperti terbatas pada populasi ibu di Belanda sehingga tidak dapat digunakan untuk karakteristik lainnya. McCaffrey membuat alat ukur Mindfulness In Parenting Questionnaire (MIPQ) pada tahun 2015 yang terdiri dari 61 aitem pada awalnya. Kemudian setelah dilakukan uji validitas dan reliabilitas kembali maka alat ukur MIPQ yang dapat digunakan terdiri dari 28 aitem. MIPQ ini dapat digunakan pada orang tua (ayah dan ibu) yang memiliki anak berusia 2-16 tahun.

Kekurangan pada alat ukur terbaru (MIPQ) dengan 28 aitem ini yaitu rendahnya reliabilitas aitem. Selain itu, aitem-aitem pada alat ukur ini belum mampu membedakan bagaimana gambaran pola asuh pada ayah dan ibu dalam menerapkan mindful parenting ini (McCaffrey, Reitman, \& Black, 2017). Dengan demikian, perlu disusun alat ukur baru yang dapat mengukur efektivitas mindful parenting yang dilakukan oleh ayah dan ibu. Selain itu, alat ukur MIPQ masih perlu dievaluasi pada dimensi being in the moment with child dan alat ukur MIPQ ini lebih akurat untuk mengukur tingkat mindful parenting yang rendah.

Berdasarkan pemaparan di atas, hipotesis pada penelitian ini adalah alat ukur mindful parenting yang dibuat oleh peneliti memiliki reliabilitas (konsistensi internal) yang tinggi, valid (dapat mengukur konstruk mindful parenting), memiliki aitem-aitem yang baik, dan memiliki norma yang baik.

\section{METODE PENELITIAN}

\section{Partisipan Penelitian}

Partisipan pada penelitian ini adalah orang tua di seluruh Indonesia yang memiliki remaja berusia 12-20 tahun. Teknik sampling yang digunakan dalam pengambilan data pada penelitian ini menggunakan non-probabilitas sampling yaitu accidental assignment/sampling. Pengambilan data secara offline, dilakukan pada orang tua dari siswa-siswa yang ada pada salah satu sekolah di Tulung Agung, Jawa Timur dan beberapa orang tua di Jabodetabek. Sedangkan beberapa data secara online diambil dari berbagai daerah di Jabodetabek maupun beberapa daerah di luar Jabodetabek. Total partisipan yang mengikuti penelitian alat ukur ini sebanyak 402 partisipan. 402 partisipan tersebut terdiri dari 231 partisipan perempuan (ibu) 
dan 171 partisipan laki-laki (ayah) dengan rata-rata umur anak 15 tahun.

\section{Prosedur Penelitian}

Prosedur penelitian untuk mengembangkan instrumen mindful parenting dilakukan melalui beberapa tahap yaitu:

\section{Tahap Persiapan}

Pada tahap awal dimulai dengan menentukan konstruk yang akan diukur yaitu mindful parenting. Definisi mindful parenting yang digunakan pada penyusunan alat ukur ini adalah definisi dari Kabat-Zinn dan Kabat-Zinn (2014) yaitu suatu tindakan pengasuhan orang tua yang berlangsung

Tabel 1

Operasionalisasi Konstruk Mindful Parenting secara terus menerus dengan tujuan untuk meningkatkan kesadaran dan kemampuan orang tua untuk hadir dan bertindak secara bijaksana terhadap anak. Berdasarkan definisi tersebut, Kabat-Zinn (2014) melihat mindful parenting terdiri dari tiga elemen yaitu pengendalian (sovereignty), empati (empathy), dan penerimaan (acceptance). Berdasarkan definisi dan elemen tersebut, peneliti kemudian mengoperasionalisasikan elemen-elemen dari mindful parenting menjadi beberapa indikator untuk tiap elemen. Operasionalisasi konstruk dari elemen-elemen mindful parenting hingga indikator dapat dilihat pada tabel 1 .

\begin{tabular}{|c|c|c|}
\hline Elemen & Definisi/Deskripsi Elemen & Indikator \\
\hline \multirow[t]{3}{*}{ Sovereignty } & \multirow{3}{*}{$\begin{array}{l}\text { Suatu kondisi ketika orang tua } \\
\text { mampu untuk mengendalikan diri } \\
\text { atau sikap dalam memahami dan } \\
\text { menghargai berbagai perilaku anak } \\
\text { disesuaikan dengan tujuan } \\
\text { pengasuhan orang tua terhadap } \\
\text { anak. }\end{array}$} & $\begin{array}{l}\text { 1. Orang tua mampu mengendalikan diri } \\
\text { ketika berinteraksi dengan anak. }\end{array}$ \\
\hline & & $\begin{array}{lllr}\text { 2. Orang tua memahami bahwa anak } \\
\text { memiliki kehendak bebas } \\
\text { karakteristik perilaku tertentu. }\end{array}$ \\
\hline & & $\begin{array}{l}\text { 3. Orang tua memahami tujuan } \\
\text { pengasuhan yang akan dicapai }\end{array}$ \\
\hline \multirow[t]{4}{*}{ Empathy } & \multirow{4}{*}{$\begin{array}{l}\text { Suatu keadaan ketika orang tua } \\
\text { dapat memahami hal yang dialami } \\
\text { dan dirasakan oleh anak sekaligus } \\
\text { memiliki kepekaan terhadap } \\
\text { kebutuhan anak serta mampu } \\
\text { memahami dirinya. }\end{array}$} & $\begin{array}{l}\text { 1. Orang tua dapat memahami dan } \\
\text { merasakan emosi yang ada pada anak. }\end{array}$ \\
\hline & & $\begin{array}{l}\text { 2. Orang tua dapat memahami emosi dan } \\
\text { kebutuhan dirinya. }\end{array}$ \\
\hline & & $\begin{array}{l}\text { 3. Orang tua dapat peka terhadap } \\
\text { kebutuhan anak. }\end{array}$ \\
\hline & & $\begin{array}{l}\text { 4. Orang tua dapat melihat berbagai hal } \\
\text { dari sudut pandang anak melalui } \\
\text { komunikasi }\end{array}$ \\
\hline \multirow[t]{6}{*}{ Acceptance } & \multirow{6}{*}{$\begin{array}{l}\text { Suatu keadaan ketika orang tua } \\
\text { mampu menerima perasaan, kondisi } \\
\text { yang terjadi pada dirinya sekaligus } \\
\text { dapat menerima perasaan anak serta } \\
\text { segala sesuatu yang ada dan terjadi } \\
\text { pada anak. }\end{array}$} & $\begin{array}{l}\text { 1. Orang tua mampu menerima perasaan } \\
\text { dan kondisi dirinya. }\end{array}$ \\
\hline & & $\begin{array}{l}\text { 2. Orang tua mampu menerima perasaan } \\
\text { dan kondisi anak. }\end{array}$ \\
\hline & & $\begin{array}{l}\text { 3. Orang tua mampu melihat niat positif di } \\
\text { balik setiap perilaku yang ditampilkan } \\
\text { anak. }\end{array}$ \\
\hline & & $\begin{array}{l}\text { 4. Orang tua dapat membantu anak untuk } \\
\text { mengekspresikan perasaannya. }\end{array}$ \\
\hline & & $\begin{array}{l}\text { 5. Orang tua dapat menemukan solusi } \\
\text { terhadap permasalahan yang dihadapi. }\end{array}$ \\
\hline & & $\begin{array}{l}\text { 6. Orang tua dapat menemukan solusi } \\
\text { terhadap permasalahan anak }\end{array}$ \\
\hline
\end{tabular}


Indikator tersebut kemudian dibuat menjadi beberapa aitem. Aitem-aitem tersebut kemudian dilihat secara kualitatif melalui pendapat dari expert judgement dan uji keterbacaan dari partisipan. Expert judgment berasal dari dosen yang ahli di bidang psikometri dan dosen yang ahli bidang pengasuhan serta memahami konsep mindfulness.

\section{Tahap Uji Keterbacaan}

Tahap yang dilakukan pertama untuk menguji coba kuesioner mindful parenting adalah dengan meminta pendapat pada expert judgement. Pendapat tersebut berupa masukan berupa kata-kata yang tidak jelas yang memiliki potensi tidak dapat dipahami oleh individu secara umum. Tahap ini dilakukan dengan memberikan kuesioner kepada 10 partisipan.

Partisipan melakukan uji keterbacaaan yaitu penilaian secara kualitatif terhadap kuesioner meliputi bentuk kuesioner, tulisan, format yang digunakan, serta aitemaitem didalamnya. Masukan dari partisipan dan pendapat ahli (expert judgement) dijadikan pertimbangan untuk merevisi aitem. Berdasarkan masukan dan pemahama partisipan, 82 aitem yang dibuat pada awalnya dipilih menjadi 60 aitem terbaik untuk pengambilan data. Berdasarkan hasil uji coba atau uji keterbacaan alat ukur mindful parenting yang diberikan pada 10 partisipan, maka terdapat 42 aitem yang dapat dipahami oleh partisipan. Sedangkan aitem-aitem yang tidak dapat dipahami atau diberikan pendapat oleh partisipan terdiri dari 18 aitem.

Ketidakpahaman atau pendapat partisipan terhadap aitem-aitem alat ukur mindful parenting terdiri dari ketidakpahaman terhadap makna kata dan kalimat, kemiripan arti antar aitem, dan ketidaksesuaian bentuk respon terhadap aitem-aitem tersebut. Berdasarkan hal tersebut dilakukan revisi terhadap aitemaitem yang dianggap tidak paham atau kurang baik. Setelah itu dilakukan uji keterbacaan kembali.

\section{Tahap Uji Coba}

Setelah dilakukan uji keterbacaan, diperoleh 60 aitem yang kemudian dilakukan uji coba kepada 30 orang. Hasil uji coba menunjukkan koefisien reliabilitas cronbach alpha sebesar 0,965 dan validitas (corrected item-total correlation) berkisar antara 0,313-0,788. Hasil tersebut menunjukkan bahwa alat ukur ini valid dan reliabel sehingga siap untuk diberikan kepada partisipan untuk pengambilan data.

\section{Tahap Pengambilan Data}

Tahap pengambilan data dilakukan selama kurang lebih 3 minggu dengan menggunakan kuesioner secara offline dan online. Pengambilan data secara offline dilakukan di Jabodetabek dan Kabupaten Tulung Agung, Jawa Timur dengan memberikan kuesioner secara langsung kepada individu yang sesuai dengan karakteristik partisipan. Sedangkan pengambilan data secara online dilakukan dengan menggunakan google forms sebagai kuesioner online.

Dalam melakukan pengambilan data, partisipan yang ditetapkan pada penelitian ini pada awalnya berjumlah 300 orang, namun dalam pelaksanaannya jumlah partisipan bertambah menjadi 465 orang. Partisipan yang memenuhi kualifikasi pada akhirnya berjumlah menjadi 402 orang, dengan perincian partisipan online 108 orang dan partisipan online yang dikeluarkan dalam penelitian berjumlah 15 orang sehingga jumlah total partisipan online 93 orang. Sedangkan partisipan yang diambil secara offline berjumlah 357 orang dan yang dikeluarkan pada penelitian berjumlah 48 orang sehingga total keseluruhan partisipan 309 orang. Sample pada penelitian yang digunakan ini cukup besar, sehingga lebih memungkinkan untuk mewakili populasi orang tua di Indonesia. Semakin besar sample yang digunakan akan memungkinkan untuk mewakili keseluruhan populasi yang ada (Field, 2016). 


\section{Instrumen Penelitian}

Alat ukur yang dikonstruksi pada penelitian ini adalah alat ukur pengasuhan orang tua yang berbasis kesadaran penuh dan bijaksana (mindful parenting). Alat ukur mindful parenting ini menggunakan skala likert dengan rentang 1-4 sehingga responden memiliki empat pilihan jawaban. Pada aitem favorable, respon dari partisipan diberikan skor yaitu 1 = tidak pernah, $2=$ kadang-kadang, $3=$ sering, $4=$ selalu, sedangkan pada aitem unfavorable diberikan skor berkebalikan dari skor pada aitem favorable, yaitu $1=$ selalu, $2=$ sering, 3 = kadang-kadang, $4=$ tidak pernah.

Alat ukur ini terdiri dari 60 aitem dengan jumlah aitem favorable sebanyak 58, sedangkan 2 aitem lainnya merupakan aitem unfavorable. Berdasarkan teori dan hasil analisis EFA (exploratory factor analysis). Alat ukur mindful parenting ini memiliki skor secara keseluruhan atau skor total karena alat ukur ini bersifat unidimensional. Dengan demikian, semakin tinggi skor yang didapatkan oleh orang tua, maka tingkat mindful parenting juga semakin tinggi, begitu pula sebaliknya, semakin rendah skor yang di dapat oleh orang tua, maka tingkat mindful parenting semakin rendah.

Alat ukur lainnya yang diberikan kepada partisipan sebagai pembanding untuk uji validitas (correlation with other test) adalah Ryff's Psychological WellBeing (RPWB). Konstruk psychological well-being dijadikan pembanding karena berdasarkan hasil penelitian yang dilakukan oleh Cachia, Anderson, dan Moore (2016) menunjukkan bahwa mindful parenting yang dilakukan oleh orang tua dapat meningkatkan psychological well-being orang tua. Berdasarkan hasil penelitian tersebut, maka alat ukur yang digunakan adalah RPWB yang dibuat oleh Rusdian pada tahun 2012 yang terdiri dari 21 aitem, dimana reliabilitas alat ukur psychological well-being ini sebesar $\alpha=0,911$ dan validitas keseluruhan antara $0,165-0,770$ (Rusdian, 2012). Alat ukur ini sudah digunakan dalam beberapa penelitian dan teruji valid untuk mengukur psychological well-being.

\section{Analisis Statistik}

Teknik pengujian yang dilakukan pada alat ukur mindful parenting ini adalah teknik pengujian reliabilitas dengan menggunakan teknik konsistensi internal Cronbach's Alpha. Teknik pengujian ini dilakukan untuk melihat homogenitas atau konsistensi aitem satu sama lain. Validitas yang akan diujikan pada alat ukur mindful parenting ini adalah construct validity dengan cara mengkorelasikan alat ukur mindful parenting dengan tes lain (correlation with other test) yang mengukur konstruk lain yang memiliki korelasi dengan konstruk yang akan diukur (convergent evidence).

Peneliti juga melakukan analisis faktor menggunakan confirmatory factor analysis (CFA) untuk melihat validitas konstruk. Kriteria (cut-off) yang digunakan untuk menguji model (goodness of fit) yaitu CFI > 0,90; RSMEA < 0,06; dan SRMR $<0,08$ (Hu \& Bentler, 1999). Di sisi lain, Ferdinand (2005) melihat cut of value RMSEA yaitu $\leq 0,08$; dan CFI semakin mendekati 1 semakin fit, yaitu $\geq 0,90$ termasuk kriteria good fit, sedangkan skor 0,80-0,89 termasuk marginal fit.

Selain itu, analisis aitem-aitem pada alat ukur mindful parenting juga dilakukan melalui melihat tingkat proporsi partisipan dalam menyetujui pernyataan yang ada pada alat ukur. Hal ini biasa disebut juga dengan proportion of endorsement yang dapat melihat tingkat social desirability pada suatu alat ukur. Tingkat diskriminasi aitem juga dilakukan untuk melihat seberapa baik aitem mampu membedakan seseorang dengan tingkat mindful parenting yang tinggi dan rendah. Hal ini disebut sebagai daya beda aitem (item discrimination).

Penyusunan norma alat ukur mindful parenting menggunakan within groupnorms dengan menggunakan standard score yaitu $t$-score $(\mathrm{SD}=10$, mean $=50)$. Pemilihan norma pada alat ukur mindful 
parenting ini bertujuan untuk dapat membandingkan hasil atau skor yang didapatkan oleh partisipan dengan kelompok partisipan pada alat ukur mindful parenting dan juga untuk melakukan interpretasi terhadap skor yang diperoleh individu tersebut.

\section{ANALISIS DAN HASIL \\ Hasil Pengujian Reliabilitas}

Reliabilitas alat ukur mindful parenting diuji menggunakan metode Cronbach Alpha untuk mengukur internal consistency dari alat ukur tersebut. Pengujian reliabilitas dengan menggunakan metode Cronbach Alpha ini dilakukan dengan menggunakan SPSS 22 dan didapatkan hasil koefisien reliabilitas alat ukur mindful parenting ini sebesar 0,950. Hal ini menunjukkan bahwa 95\% dari varians observed score merupakan varians true score dan 5\% merupakan varians error yang disebabkan oleh content sampling error dan content heterogeneity. Berdasarkan hasil tersebut dapat disimpulkan bahwa alat ukur mindful parenting reliabel karena memiliki internal consistency yang tinggi. Selain itu, nilai koefisien corrected item-total correlation pada 60 aitem berkisar antara -0,95-0,66. Terdapat empat aitem yang memiliki koefisien yang tidak baik yaitu kurang dari 0,30 .

\section{Hasil Pengujian Validitas Correlation With Other Test}

Hasil uji validitas yang dilakukan dengan mengkorelasikan alat ukur mindful parenting dengan alat ukur psychological well-being didapatkan hasil koefisien korelasi $(\mathrm{r}=0,396 ; \quad \mathrm{p}<0,01)$. Hal ini menunjukkan bahwa terdapat $15,7 \%$ proporsi varians psychological well-being dijelaskan oleh mindful parenting, sehingga dapat disimpulkan bahwa mindful parenting memiliki korelasi positif dengan psychological well-being orang tua secara signifikan dan hasil ini sesuai dengan penelitian yang dilakukan oleh Cachia, Anderson, dan Moore (2016) mengenai mindfulness, stress, dan well-being pada orang tua yang memiliki anak dengan autism spectrum disorder, yang menunjukkan hasil bahwa mindfulness intervention yang dilakukan pada orang tua dapat meningkatkan psychological wellbeing orang tua.

\section{Hasil Analisis Aitem \\ Item Discrimination (CrIT)}

Aitem memiliki daya beda yang baik jika korelasi aitem dengan skor total sebesar $>0,30$ (Field, 2013). Berdasarkan nilai item-total correlation terdapat empat aitem yang tidak memenuhi kriteria daya beda yang baik.

\section{Proportion of Endorsement (PoE)}

Aitem dikatakan memiliki proportion of endorsement yang baik apabila memiliki proportion of endorsement yang berada pada rentang 0,3 - 0,8 (Cohen \& Swerdlik, 2009). Berdasarkan hasil proportion of endorsement didapat 19 aitem yang tidak memenuhi kriteria dari Proportion of Endorsement.

\section{Factor Loadings CFA}

Suatu aitem dapat dikatakan memiliki factor loadings yang baik apabila memiliki nilai factor loadings $>0,40$ (Field, 2013). Hasil CFA menunjukkan terdapat 11 aitem yang tidak memenuhi kriteria dari factor loading karena memiliki nilai $<0,40$.

\section{Analisis Integratif}

Berdasarkan pertimbangan dari hasil mengevaluasi aitem secara kualitatif dan kuantitatif dengan melihat item-total correlation, proportion of endorsement, dan factor loadings CFA, maka didapatkan 30 aitem yang dipertahankan dan 30 aitem yang dibuang tanpa melakukan revisi terhadap aitem karena memiliki koefisien yang kurang baik dalam ketiga indikator tersebut. 


\section{Hasil Pengujian Kembali Reliabilitas dan Validitas dari Aitem-Aitem Terpilih}

Setelah melakukan analisis aitem dan didapatkan 30 aitem terpilih, dilakukan pengujian kembali terhadap reliabilitas dan validitas alat ukur dari 30 aitem tersebut. Hasil pengujian reliabilitas menggunakan cronbach alpha menunjukkan koefisien sebesar 0,933. Hasil tersebut menunjukkan bahwa 93,3\% dari varians observed score merupakan varians true score dan 0,5\% merupakan varians error yang disebabkan oleh content sampling error dan content heterogeneity. Berdasarkan hasil tersebut dapat disimpulkan bahwa alat ukur mengalami penurunan koefisien reliabilitas sebesar 0,017 setelah mengeliminasi aitemaitem namun masih tetap reliabel karena masih memiliki koefisien reliabilitas yang tinggi.

Peneliti juga melakukan pengujian kembali validitas alat ukur dengan menggunakan correlation with other test dan CFA pada 30 aitem terpilih. Hasil korelasi antara alat ukur mindful parenting dan alat ukur psychological well-being menunjukkan bahwa terdapat hubungan yang positif secara signifikan antara total skor mindful parenting dan skor total psychological well-being pada orang tua $(\mathrm{r}=0,362 ; \mathrm{p}<0,01 ;$ one tailed $)$. Hal ini menunjukkan bahwa $13,1 \%$ proporsi varians psychological well-being dijelaskan oleh mindful parenting. Berdasarkan hasil tersebut dapat disimpulkan bahwa alat ukur mindful parenting mengalami penurunan koefisien validitas sebesar 0,034 .

Hasil confirmatory factor analysis (CFA) terhadap 30 aitem menunjukkan nilai robust CFI 0,871, RMSEA 0,058 dan SRMR 0.051. Hasil tersebut menunjukkan bahwa dua kriteria goodness of fit yaitu RMSEA dan SRMR terpenuhi dengan baik (good fit), sedangkan CFI berada pada kriteria cukup baik (marginal fit). Berdasarkan hasil CFA tersebut, maka dapat disimpulkan bahwa alat ukur mindful parenting valid untuk mengukur konstruk mindful parenting dan data di lapangan sesuai dengan model yang diajukan berdasarkan teori dari Jon Kabat-Zinn dan Myla Kabat-Zinn (2014) mengenai mindful parenting.

\section{Hasil Penyusunan Norma}

Berdasarkan hasil dari analisis aitem tersisa 30 aitem dengan rentang jawaban 14 sehingga jawaban terendah dari alat ukur mindful parenting memiliki nilai " 1 " dan jawaban tertinggi memiliki nilai "4". Artinya skor terendah yang mungkin partisipan dapat sebesar 30 dan skor tertinggi yang mungkin partisipan dapat sebesar 120. Setelah mendapat 30 aitem dari hasil analisis aitem, kemudian peneliti melakukan uji normalitas data dengan melihat nilai skewness dan kurtosis. Pemilihan teknik uji normalitas ini karena dengan sampel yang cukup tinggi, teknik uji normalitas seperti Kolmogorov Smirnov cenderung menghasilkan data yang normal.

Hasil uji statistik deskriptif menunjukkan nilai skewness sebesar 0,252 dan nilai kurtosis sebesar - 0,007. Artinya data yang didapatkan sudah terdistribusi normal karena nilai skewness dan kurtosis berada direntang -3 dan +3 (Cohen \& Swerdlik, 2009). Norma alat ukur mindful parenting ini diperoleh melalui transformasi linear dengan menggunakan $T$ score (mean $=50, \mathrm{SD}=10$ ). Hasil dari penyusunan norma menunjukkan bahwa alat ukur mindful parenting memiliki norma yang baik.

\section{DISKUSI}

Setelah melakukan analisa terhadap alat ukur mindful parenting, didapatkan nilai koefisien alpha pada reliabilitas yang tergolong tinggi, baik pada 60 aitem maupun setelah melakukan analisis aitem dan tersisa 30 aitem. Berdasarkan studi sebelumnya mengenai alat ukur mindful parenting terdahulu, ditemukan reliabilitas yang belum baik (McCaffrey, Reitman, \& Black, 2017). Hal ini berbeda dengan hasil penelitian ini yang menunjukkan reliabilitas yang tinggi dalam mengukur mindful parenting. 
Selain itu, pengujian validitas pada alat ukur mindful parenting ini menunjukkan bahwa alat ukur mindful parenting ini valid untuk mengukur konstruk mindful parenting. Hal ini dapat terlihat dari hasil korelasi dengan alat ukur psychological well-being yang signifikan dan positif. Hasil ini sesuai dengan penelitian sebelumnya yang menunjukkan bahwa mindful parenting yang dilakukan oleh orang tua berhubungan dengan psychological well-being orang tua (Cachia, Anderson, \& Moore, 2016). Hasil korelasi yang positif dan signifikan antara alat ukur mindful parenting dan alat ukur psychological well-being menunjukkan alat ukur mindful parenting yang dikembangkan memiliki validitas konstruk yang baik. Hal ini sejalan dengan pendapat Cohen (2009) mengenai uji validitas konstruk dengan teknik convergent evidence yaitu mengkorelasikan alat ukur kita dengan alat ukur lain yang mengukur konstruk yang berkorelasi positif dengan konstruk pada alat ukur kita.

Analisis faktor yang dilakukan terhadap konstruk mindful parenting menunjukkan model yang fit. Hal ini menunjukkan bahwa data di lapangan sesuai dengan model yang diajukan. Hasil tersebut sesuai dengan model yang diajukan oleh Kabat-Zinn \& Kabat-Zinn (2014) mengenai mindful parenting yang bersifat unidimensional dan terdiri dari tiga elemen yaitu sovereignty, empathy, acceptance.

Alat ukur mindful parenting ini juga menunjukkan kualitas aitem yang baik, terlihat dari hasil analisis aitem dengan $\mathrm{PoE}$ dan $\mathrm{Cr}_{\text {IT }}$ yang cukup baik. Hal ini berbeda dengan penelitian sebelumnya yang menunjukkan bahwa alat ukur mindful parenting terdahulu kurang dapat membedakan tingkat mindful parenting orang tua yang tinggi dan rendah (McCaffrey, Reitman, \& Black, 2017). Penelitian ini menunjukkan kualitas aitem yang baik sehingga mampu membedakan tingkat mindful parenting orang tua. Walaupun begitu, hasil ini dapat disebabkan karena adanya kesamaan karakteristik dari partisipan sehingga data yang didapatkan kurang bervariasi dari berbagai wilayah di Indonesia. Hal tersebut menjadi keterbatasan dalam penelitian ini.

Berdasarkan hasil di atas, dapat dikatakan bahwa alat ukur mindful parenting ini dapat melengkapi keterbatasan dan kekurangan pada alat ukur mindful parenting lainnya yang sudah ada selama ini.

\section{SIMPULAN}

Berdasarkan hasil penelitian tentang alat ukur mindful parenting yang telah dilakukan dapat disimpulkan bahwa hasil uji reliabilitas menggunakan metode Cronbach Alpha untuk mengukur konsistensi internal menunjukkan bahwa alat ukur mindful parenting merupakan alat ukur yang reliabel. Berdasarkan uji validitas konten yang dilakukan juga menunjukkan bahwa aitem-aitem yang ada pada alat ukur mindful parenting sudah dapat mengukur konstruk mindful parenting.

Hasil uji validitas konstruk menunjukkan bahwa konstruk mindful parenting berkorelasi dengan psychological well-being orang tua. Artinya, aitem-aitem yang ada pada alat ukur mindful parenting mampu mengukur konstruk mindful parenting dan sesuai dengan teori yang diajukan oleh John Kabat-Zinn dan Myla Kabat-Zinn (2014) mengenai mindful parenting terbukti. Maka dapat disimpulkan bahwa alat ukur mindful parenting ini valid dalam mengukur konstruk mindful parenting.

Setelah dilakukan analisis aitem berdasarkan kualitatif dan kuantitatif dengan melihat nilai daya beda aitem (Crit), proportion of endorsemen $(\mathrm{PoE})$, dan factor loading dari CFA didapatkan 30 aitem yang dipertahankan dan 30 aitem yang dieliminasi tanpa merevisi aitem tersebut. Hasil dari penyusunan norma terhadap 30 aitem menunjukkan bahwa alat ukur mindful parenting memiliki norma yang baik. Norma alat ukur mindful parenting ini diperoleh dari hasil transformasi linear 
dengan menggunakan $\mathrm{T}$-Score $($ mean $=50$, $\mathrm{SD}=10)$.

Selain itu, berdasarkan penelitian sebelumnya, alat ukur mindful parenting terdahulu belum melihat tingkat mindful parenting orang tua di rentang usia remaja Indonesia (McCaffrey, Reitman, \& Black, 2017). Di sisi lain, penelitian ini mencoba fokus pada usia remaja di Indonesia sehingga dapat digunakan untuk melihat mindful parenting orang tua melalui cakupan usia yang lebih merepresentasikan remaja di Indonesia.

\section{SARAN}

Terdapat beberapa hal yang perlu ditinjau kembali terkait penelitian alat ukur mindful parenting ini agar kualitas alat ukur mindful parenting ini meningkat. Salah satunya yaitu karakteristik partisipan yang lebih beragam lagi dari berbagai budaya di Indonesia. Hal ini bertujuan agar dapat lebih merepresentasikan populasi yaitu orang tua di Indonesia. Selain itu, untuk penelitian selanjutnya dapat dilakukan pengambilan data ulang untuk kembali menguji coba 30 aitem yang didapat dari hasil akhir analisis aitem pada penelitian alat ukur mindful parenting ini. Selain itu, dapat pula dilakukan studi selanjutnya dengan membandingkan pada beberapa kelompok usia orang tua (orang tua berusia 20 tahun dengan orang tua berusia 40 tahun) atau kelompok orang tua dengan anak berusia lain (orang tua dengan anak balita atau orang tua dengan anak SD).

Pengembangan alat ukur ini dapat menjadi instrumen untuk mengetahui tingkat mindful parenting orang tua di Indonesia yang kemudian dapat digunakan untuk membuat penyuluhan terkait mindful parenting pada orang tua dengan anak berusia remaja. Alat ukur ini juga dapat digunakan oleh tenaga konselor atau psikolog sebagai dasar untuk memberikan intervensi terhadap orang tua dari remaja di Indonesia.

\section{DAFTAR PUSTAKA}

Bluth, K., \& Wahler, R. G. (2011). Does effort matter in mindful parenting? Mindfulness, 2(3), 175-178. doi 10.1007/s12671-011-0056-3.

Cabrera, N. J., Fitzgerald, H. E., Bradley, R. H., \& Roggman, L. (2014). The ecology of father-child relationships: An expanded model. Journal of Family Theory \& Review, 6(4), 336-354. doi $10.1111 /$ jtr.12054.

Cachia, R. L., Anderson, A., \& Moore, D. W. (2016). Mindfulness, stress and well-being in parent of children with autism spectrum disorder: A systematic review. Journal of Child and Family Studies, 25(1), 1-14. doi 10.1007/s10826-015-0193-8.

Chapple, C. L., Tyler, K. A., \& Bersani, B. E. (2005). Child neglect and adolescent violence: examining the effects of self-control and peer rejection. Violence and Victims, 20(1), 39-53.

Coatsworth, J. D., Duncan, L. G., Greenberg, M. T., \& Nix, R. L. (2009). Changing parent's mindfulness, child management skills and relationship quality with their youth: Results from a randomized pilot intervention trial. Journal of Child and Family Studies, 19(2), 203-217. doi 10.1007/s10826-009-9304-8.

de Bruin, E. I., Zijlstra, B. J., Geurtzen, N., van Zundert, R. M., van de WeijerBergsma, E., Hartman, E. E., ... \& Bögels, S. M. (2014). Mindful parenting assessed further: Psychometric properties of the Dutch version of the Interpersonal Mindfulness in Parenting Scale (IMP). Mindfulness, 5(2), 200-212.

Duncan, Larissa G. (2007). Assessment of mindful parenting among parents of early adolescents: development and validation of interpersonal mindfulness in parenting scale (Doctoral dissertation, The 
Pennsylvania State University, Amerika Serikat). Retrieved from https://etda.libraries.psu.edu/files/fin al submissions/3737.

Duncan, L. G., Coatsworth, J. D., \& Greenberg, M. T. (2009). A model of mindful parenting: Implications for parent-child relationships and prevention research. Clinical Child and Family Psychology Review, 12(3), 255-270. doi 10.1007/s 10567-009-0046-3.

Duncan, L. G., Coatsworth, J. D., \& Greenberg, M. T. (2009). Pilot study to gauge acceptability of a mindfulness-based, family-focused preventive intervention. Journal Primary Prevent, 30(5), 605-618. doi 10.1007/s10935-009-0185-9.

Feist, J., \& Feist, G. J. (2008). Theories of personality (7th ed.). USA: McGraw-Hill Companies, Inc.

Ferdinand, A., T. (2005). Structural equation modelling. Semarang: Badan Penerbit Universitas Diponegoro.

Glatz, T. \& Buchanan, C. M. (2015). Overtime associations among parental self-efficacy, promotive parenting practices and adolescents externalizing behavior. Journal of Family Psychology, 29(3), 427-437. doi 10.1037/fam0000076.

Hu, L. T., \& Bentler, P. M. (1999). Cutoff criteria for fit indexes in covariance structure analysis: Conventional criteria versus new alternatives. Structural Equation Modeling: A Multidisciplinary journal, 6(1), 1-55.

Kabat-Zinn, M., \& Kabat-Zinn, J. (2014). Everyday blessings: The inner work of mindful parenting. New York, New York: Hyperion.

Kabat-Zinn, J., \& Williams, M.G. (2013). Mindfulness diverse perspectives on its meaning, origins, and applications. USA: Routledge.

McCaffrey, Stacey., Reitman, David., \& Black, Ryan. (2017). Mindfulness in parenting questionnaire (mipq): Development and validation of a measure of mindful parenting. Journal Mindfulness, 8(1), 232-246. doi 10.1007/s12671-016-0596-7.

Medeiros, C., Gouveia, M. J., Canavarro, M. C., \& Moreira, H. (2016). The indirect effect of the mindful parenting of mothers and fathers on the child's perceived well-being through the child's attachment to parents. Mindfulness, 7(4), 916-927. Doi 10.1007/s12671-016-0530-z.

Moreira, H., Gouveia, M. J., \& Canavarro, M.C. (2018). Is mindful parenting associated with adolescents wellbeing in early and middle/late adolescence? The mediating role of adolescents' attachment representations, self-compassion and mindfulness. Journal of Youth and Adolescence, 47(8), 1771-1788. doi https://doi.org/10.1007/s10964018-0808-7.

Parent, J., McKee, L. G., Rough, J. N., \& Forehand, R. (2015). The association of parent mindfulness with parenting and youth psychopathology across three developmental stages. Journal of Abnormal Child Psychology, 44(1), 191-202. doi 10.1007/s10802-0159978-x.

Rusdian, C. (2012). Hubungan antara psychological well-being dan keterlibatan orang tua dalam pendidikan anak disabilitas intelektual usia kanak-kanak (4-11 tahun) (Skripsi). Universitas Indonesia, Depok, Indonesia.

Zaslow, M. J., Weinfield, N. S., Gallagher, M., Hair, E. C., Ogawa, J. R., Egeland, B., Tabors, P.O., \& De Temple, J. M. (2006). Longitudinal prediction of child outcomes from differing measures of parenting in a low-income sample. Developmental Psychology, 42(1), 27-37. doi 10.1037/0012-1649.42.1.27. 